\title{
Evaluating Technical Efficiency of Turkish Sugar Production in Pre and Post Privatization Periods
}

\author{
Yetkin ÇINAR (https://orcid.org/0000-0002-4710-0346), Department of Business Administration, Ankara \\ University, Turkey; e-mail: ycinar@ankara.edu.tr
}

Kazım Barış ATICI (https://orcid.org/0000-0003-0786-9641), Department of Business Administration, Hacettepe University, Turkey; e-mail: kba@hacettepe.edu.tr

Cem MENTEN (https://orcid.org/0000-0003-0259-3770), Department of Business Administration, Hacettepe

University, Turkey; e-mail: menten08@hacettepe.edu.tr

\section{Türk Şeker Üretiminin Özelleştirme Öncesi ve Sonrası Teknik Etkinliğinin Değerlendirilmesi}

\begin{abstract}
The sugar production sector of Turkey has undergone a large-scale privatization in 2018. Since then, 10 out of 33 sugar factories have been privatized. The objective of this research is to investigate the effects of the privatization on the technical efficiency of the sugar factories. For this purpose, the data of 31 factories operating in different parts of the country are utilized. We evaluate the efficiency before and after privatization in two periods: pre-privatization (September 2017 - August 2018) and after-privatization (August 2018 - September 2019) using Data Envelopment Analysis, Malmquist Productivity Index and DEA by Sequential Exclusion of Alternatives methods. First, while results derived from all models reveal a technical efficiency decline among factories in general, the privatized factories stand out as the only subset that experience an increase in technical efficiency for the period analysed. Secondly, the benchmarks for the inefficient factories are identified in the short term and the long term using 'DEA by Sequential Exclusion of Alternatives' to assist improvement decisions. Finally, the research presents some methodological insights on the application of the 'DEA by Sequential Exclusion of Alternatives' approach by experimenting with changing parameters that have the potential to aid future applications.
\end{abstract}

Keywords

JEL Classification Codes :

Sugar Production, Technical Efficiency, Data Envelopment Analysis, Privatization.

\section{C14, D24, L33, L66.}

\section{Öz}

2018 yılında Türk şeker sanayisi büyük ölçekli bir özelleştirmeyi tecrübe etmiştir. O y1l, 33 șeker fabrikasından 10 adeti özelleștirilmiştir. Bu araștırmanın amacı, bu özelleștirmelerin fabrikaların Teknik etkinliğine olan etkisini gözlemlemektir. Bu amaçla ülkenin çeşitli bölgelerinde yer alan 31 adet fabrikanın verisi kullanılmaktadır. Teknik etkinlik, Veri Zarflama Analizi (VZA), Malmquist Verimlilik Endeksi ile Alternatiflerin sıralı hariç tutulmasına dayalı VZA yöntemleri kullanılarak iki dönem için değerlendirilmektedir: özelleştirme öncesi (Eylül 2017 - Ağustos 2018) ve özelleştirme sonrası (Ağustos 2018 - Eylül 2019). Sonuçlar, öncelikle, analiz edilen dönemler arasında genel anlamda bir etkinlik düşüşüne işaret etmektedir. Bununla beraber, özelleşen fabrikalar etkinlikte artış gösteren tek alt küme olmaktadır. Araştırma, etkin olmayan fabrikalar için alternatiflerin sıralı hariç tutulmasına dayalı VZA kullanılarak elde edilen referans kümelerini de sunmaktadır. Çalışma ayrıca bu metodun gelecek uygulamalarına bir kavrayış sağlama amacına yönelik parametre değerlerinin değiştirilmesine dayanan testler de içermektedir. 
Çınar, Y. \& K.B. Atıcı \& C. Menten (2021), "Evaluating Technical Efficiency of Turkish

Sugar Production in Pre and Post Privatization Periods", Sosyoekonomi, 29(47), 59-78.

Anahtar Sözcükler $\quad$ : Şeker Üretimi, Teknik Etkinlik, Veri Zarflama Analizi, Özelleştirme.

\section{Introduction}

Sugar is produced either from sugar cane or sugar beet in more than 100 countries in the world. While sugar cane constitutes $78 \%$ of the global sugar production, sugar beet corresponds to $22 \%$. Following Russia, France, Germany, and the United States, Turkey is ranked as the fifth country in the world producing sugar from beets and the fourth country in Europe. The share of the country in the world's sugar beet production is about $7 \%$ (FO Licht, 2019). In the 2018/2019 marketing period, with the increase in quotas, 20.5 million metric tons (MMT) of sugar beet have been produced in the 335,000 hectares (ha) harvesting area (USDA, 2019).

Recently, the sugar production sector of Turkey has experienced large scale privatization. 10 out of 33 sugar factories have been privatized during 2018 and the plan is to resume privatization during 2020 (USDA, 2019). The privatization in Turkish sugar production is important since the factories play an eminent role in the economy of the provinces they are located. Such a large-scale privatization may have effect on the labor force through massive layoffs and on the producers \& organizations take part in sugar production (Cicek \& Sahin, 2018). In this research, the main objective is to investigate the effects of this mass privatization on the technical efficiency of the sugar factories. For this purpose, we utilize the data of 31 factories operating in different parts of the country and evaluate the efficiency before and after privatization in two periods. The first period covers pre-privatization (September 2017 - August 2018) and the second one covers postprivatization (August 2018 - September 2019).

The methodology of the research is mainly based on the Data Envelopment Analysis (DEA). DEA, proposed by Charnes et al. (1978), is a well-known linear programming-based methodology for efficiency evaluation, in which homogeneous Decision-Making Units (DMUs) producing multiple outputs through the use of multiple inputs are evaluated relative to a non-parametric efficient frontier. The method produces relative efficiency scores for the evaluated units between 0 and 1 as well as benchmark units for the inefficient units, which is valuable for decision-making for future advancements. Build upon DEA, the change of the scores from one period to another is usually measured with Malmquist Productivity Index (MPI) approach developed by Caves et al. (1982) and Färe et al. (1992). One of the major application areas of DEA and MPI is agricultural production (see Emrouznejad et al., 2008; Atici \& Podinovski, 2012). It has been applied to evaluate efficiency in sugar production as well (see Section 2 for a brief review).

In theory, one of the main assumptions of the DEA method is the homogeneity of the evaluated units. However, derivations of the method to deal with potential heterogeneity of the units have been introduced in the literature. One of the methods that enable us to handle heterogeneity is DEA by Sequential Exclusion of Alternatives (DEA-SEA) proposed by Aleskerov \& Petrushchenko (2013; 2015) and Abankina et al. (2016). The method relies on 
adjustment of the efficient units to the barycentre of the production set so that the potential drawbacks of heterogeneity and outliers are undermined. Furthermore, since the frontier approaches the barycentre, it is possible to obtain more attainable targets for the inefficient units for the shorter terms. Since our data set consists of both public, private and privatized factories operating in different regions of the country and therefore, heterogeneity to some extent can be assumed, we also employ DEA-SEA methodology for both periods and observe the changes. The method is also applied since it has a potential to produce longer and shorter-term reference sets and these sets can provide insight for future decisions at factory level.

The contributions of the research are threefold. First of all, we investigate the effects of recent privatization on the sugar factories of Turkey comprehensively and reveal a technical efficiency increase after privatization from different angles. Secondly, the research also provides benchmarking information for the inefficient factories in the short term and the long term to assist enhancement decisions. Finally, we present methodological insights on the DEA-SEA approach in a first-time application of the method in agricultural sectors through experimenting with changing parameters that have the potential to aid future applications.

The current paper is organized as follows. Section 2 provides the related literature on efficiency measurement in sugar farming and production. In Section 3, we present the basics of the methods used in the research. Section 4 presents the findings of the empirical analysis together with the description of the data. Finally, Section 5 concludes with the implications of the findings.

\section{Previous Research on Efficiency in Sugar Production}

The top ten sugar-producing countries in the world (India, Brazil, Thailand, China, USA, Mexico, Russia, Pakistan, France, and Australia) supply almost $70 \%$ of global production in 2018-2019 (October-September season). In the literature, it is possible to find a wide range of research that efficiency measurement methods have been applied in both sugar farming and production of various countries including the leading ones. Table 1 presents a sample of the research that focuses on efficiency at two different levels as factorylevel and farm-level. The majority of the research has been conducted in Asian countries such as India, Iran, Pakistan, Thailand, and China. There also exists research that focuses on the sugar production sectors of European countries such as the Netherlands, Hungary, Ireland, Denmark, Ukraine, and Turkey.

Applied methods can be considered in two categories as parametric and nonparametric approaches. Usually, a single modelling approach has been employed. On the non-parametric side, the research is dominant with Data Envelopment Analysis. On the parametric side, Stochastic Frontier Analysis is the dominant methodology. Studies employing both types also exist (Wu et al., 2003; Mulwa et al., 2009).

It is also observed the greater number of the research deals with multiple periods, hence, with panel data. In DEA research it is common to use Malmquist Productivity Index 
(MPI) to observe the changes in efficiency over time (e.g. Raheman et al., 2009; Ye et al., 2016).

Table: 1

A Sample of Efficiency Research on Sugar Production

\begin{tabular}{|c|c|c|c|c|}
\hline Study & Country & Period & Level & Method \\
\hline Ferrantino \& Ferrier (1995) & India & $1980-1985$ & Factory-level & SFA \\
\hline Johnson et al. (1995) & USA & 1986-1992 & Factory-level & SFA \\
\hline De Koeijer et al. (2002) & Netherlands & 1994-1997 & Farm-level & DEA \\
\hline Wu et al. (2003) & USA & not noted & Farm-level & NPM \& TOBIT \\
\hline Fogarasi (2006) & Hungary & $2004-2005$ & Farm-level & DEA \& MPI \\
\hline Murty et al. (2006) & India & 1996-1999 & Factory-level & MPI \\
\hline Bogetoft et al. (2007) & Denmark & 2003 & Farm-level & DEA \\
\hline Mulwa et al. (2009) & Kenya & $1980-2000$ & Factory-level & DEA \& SFA \\
\hline Goncharuk(2009) & Ukraine & 2006 & Factory-level & DEA \\
\hline Raheman et al. (2009) & Pakistan & $1998-2007$ & Factory-level & DEA \& MPI \\
\hline Demirtas (2011) & Turkey & $2009-2010$ & Factory-level & DEA \\
\hline Kumar \& Arora (2011) & India & $2003-2004$ & Factory-level & DEA \\
\hline Patlolla et al. (2012) & India & $1992-2007$ & Factory-level & SFA \\
\hline Palcic \& Reeves (2015) & Ireland & $1984-2000$ & Factory-level & TFP \\
\hline Ye et al. (2016) & China & $2004-2013$ & Farm-level & DEA \& MPI \\
\hline Borgheipour et al. (2017) & Iran & 2002 & Factory-level & DEA \\
\hline Murali \& Prathap (2017) & India & 2011-2013 & Farm-level (Cane) & SFA \\
\hline Ullah et al. (2019) & Thailand & not noted & Farm-level (Cane) & DEA \\
\hline Duarte et al. (2019) & Brazil & $2010-2014$ & Factory-level & DEA \\
\hline
\end{tabular}

Abbreviations: DEA: Data Envelopment Analysis, SFA: Stochastic Frontier Analysis, MPI: Malmquist Productivity Index, NPM: Non-parametric Methods, TFP: Total Factor Productivity.

The privatization of the sugar production entities is of interest in various research. The impact of privatization on technical efficiency has been measured and discussed. For instance, Mulwa et al. (2009) analyse the change in efficiency before and after the privatization of the firms (in 1992) operating in the sugar industry in Kenya for the 19802000 period by using Data Envelopment Analysis and Stochastic Frontier Analysis approaches. Interestingly, no statistically significant difference is detected between the two periods. However, they reveal a decline in efficiency levels between the years 1992 and 1998 followed by an increase in the succeeding years. Palcic \& Reeves (2015) study the financial and economic performance of Irish Sugar Company for 10 years before and after privatization. Although the company exhibited rapid growth and recovery in the preprivatization period, it has been detected that privatization has no strong relationship with financial performance and productivity. The company's food division's performance has been greatly influenced by its exposure to market forces after privatization. However, surprisingly, there has been no improvement in overall performance in a highly competitive environment.

The privatization of Turkish sugar factories has been on the agenda for several years. In an earlier study than this current research Demirtas (2011) mentions the importance of investigating the Turkish Sugar Inc., which is one of the most important companies in Turkey and holding the 25 sugar factories in the year of the research. It is stated that the efficiency values calculated with the help of the DEA-based clustering approach can guide the decision-makers in the privatization process. However, privatization has not taken place until 2018. 


\section{Methodology}

\subsection{Data Envelopment Analysis (DEA)}

Data Envelopment Analysis (DEA) is a well-established non-parametric method aiming to identify relative efficiency of homogeneous Decision-Making Units (DMUs) producing multiple outputs through the use of multiple inputs. DEA has presented to the literature by the seminal research of Charnes et al. (1978). The efficiency of a DMU is measured relative to all other DMUs with the simple restriction that all DMUs lie on or below an efficient frontier (Seiford \& Thrall, 1990).

Let us consider $n$ decision-making units. We assume that each decision-making unit $j$ for $j=1,2, \ldots, n$ uses $m$ different inputs. $x_{i j}$. For $\mathrm{i}=1,2, \ldots, m$ and produces $s$ different outputs. $y_{r j}$. For $r=1,2, \ldots, s$. Let $\phi$ represent the efficiency score for unit $o$. Variables $\lambda_{j}$ are introduced corresponding to each decision-making unit $(j=1,2, \ldots, n)$ to form a Production Possibility Set (PPS) consisting of observed units, their convex combinations, scaled units (because Constant Returns-to-Scale (CRS) is assumed) and outperformed units. The units on the boundary (frontier) of the PPS are defined as efficient and attains the efficiency score of $100 \%$, where the efficiency scores for others are measured relative to the frontier. The linear programming formulation to calculate the efficiency score of unit o is given below:

$\operatorname{Max} \phi$

s.t.

$$
\begin{array}{ll}
\sum_{j=1}^{n} \lambda_{j} x_{i j} \leq x_{i o} & i=1,2, \ldots, m \\
\sum_{j=1}^{n} \lambda_{j} y_{r j} \geq \phi y_{\text {ro }} & r=1,2, \ldots, s \\
\lambda_{j} \geq 0 & j=1,2, \ldots, n
\end{array}
$$

\subsection{Malmquist Productivity Index (MPI)}

DEA models provide efficiency measurement at a point in time $\left(\right.$ Let $D_{o}^{t}\left(x^{t}, y^{t}\right)=$ $\phi)$. Malmquist Productivity Index (MPI) approach (Caves et al., 1982; Färe et al., 1992) is developed and widely used to observe the changes in productivity during a period. In order to measure the change from one period to another MPI is calculated for each unit. MPI consists of two components as Efficiency Change (EC) and Frontier Shift (FS). Efficiency Change component refers to the ratio of efficiency score in period $t+1$ to the efficiency score in period $t$. This measure itself is not enough to identify the change in productivity from one period to another because these scores are relative to different frontiers. Therefore, it is essential to measure the change in the frontier from one period to another. This is the second component of the MPI known as Frontier Shift. The calculation of $E C$ and $F S$ components for a unit is given below:

$$
E C=\frac{D_{o}^{t+1}\left(x^{t+1}, y^{t+1}\right)}{D_{o}^{t}\left(x^{t}, y^{t}\right)}
$$




$$
F S=\left[\left(\frac{D_{o}^{t}\left(x^{t+1}, y^{t+1}\right)}{D_{o}^{t+1}\left(x^{t+1}, y^{t+1}\right)}\right) *\left(\frac{D_{o}^{t}\left(x^{t}, y^{t}\right)}{D_{o}^{t+1}\left(x^{t}, y^{t}\right)}\right)\right]^{1 / 2}
$$

Once, both components are calculated relying on the linear programs, MPI of a unit is calculated as given below (given as $M_{O}\left(x^{t+1}, y^{t+1}, x^{t}, y^{t}\right)$ to represent the change from period $t$ to $t+1$.

$$
M_{O}\left(x^{t+1}, y^{t+1}, x^{t}, y^{t}\right)=\left[\left(\frac{D_{o}^{t}\left(x^{t+1}, y^{t+1}\right)}{D_{o}^{t}\left(x^{t}, y^{t}\right)}\right)\left(\frac{D_{o}^{t+1}\left(x^{t+1}, y^{t+1}\right)}{D_{o}^{t+1}\left(x^{t}, y^{t}\right)}\right)\right]^{1 / 2}
$$

\subsection{DEA by Sequential Exclusion of Alternatives}

Since the introduction of the original DEA approach, various theoretical and methodological improvements have been carried out. As one of the recent developments, Aleskerov \& Petrushchenko (2013; 2015) propose, Cinar (2013) and Abankina et al. (2016) apply a new DEA methodology that enables assessment of the efficiency by adjusting the frontier by taking heterogeneity of the units into account. In highly heterogeneous data sets, many inefficient units have to be benchmarked against some exceptional ones which are very rare in the sample. One can assert that it is not fair and not practical when obtaining the reference sets. To overcome this issue, Aleskerov \& Petrushchenko $(2013 ; 2015)$ propose to adjust the efficiency frontier towards the barycentre of the units. To achieve this, the method is based on the sequential exclusion of alternatives with DEA iterations; therefore, it is referred as DEA by Sequential Exclusion of Alternatives (DEA-SEA) method. The approach can be illustrated via a graphical representation given in Figure 1 (Aleskerov \& Petrushchenko, 2013; 2015; Cinar, 2013; Abankina et al., 2016).

Figure: 1

\section{Graphical Interpretation of DEA-SEA Method}

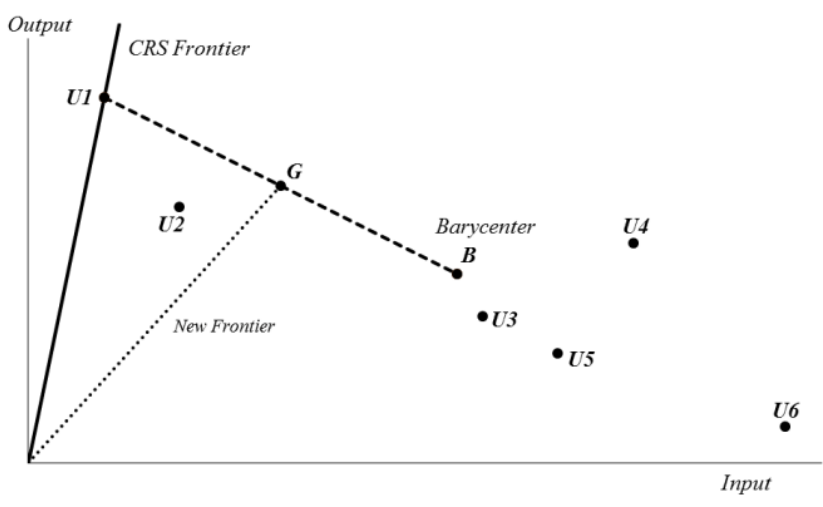

In Figure 1, a set of decision-making units (DMUs), $U 1$ to $U 6$ are given. According to the standard DEA (CRS) model, a vast majority of inefficient DMUs (U3,U4, U5, and U6) are located very far from the efficient frontier formed by unit $U 1$ which can be seen as an outlier in the sample. In other words, $U 1$ exhibits an exceptional efficiency via standard DEA calculation that when the other units are benchmarked against $U 1$, their scores are 
partially undervalued. From this point of view, the DEA-SEA approach asserts that the inefficient units can be evaluated less strictly than the case of the standard DEA model. For this aim, the method proposes the following steps:

- Firstly, the barycentre of all units (point $B$ in Figure 1) is calculated in the usual geometrical or analytical sense. It means that the point $B$ has $i$-th input (output) equal to the average of all the $i$-th input (output) in the whole sample (Abankina et al., 2016).

- As a second step, a new frontier is constructed via generating an imaginary unit $G$ lying on the segment $B U 1$ and by moving the frontier towards point $G$. The location of the unit $G$ is identified by some extent to heterogeneity through $\mu$ and it is defined as:

$G=\mu B+(1-\mu) U 1$

- Here, the index $\mu$ stands for the degree of adjustment for heterogeneity. It is between 0 and 1 . The higher $\mu$ the nearer $G$ to the barycentre $B$.

- As the next step, using DEA methodology the units $U 3, U 4, U 5$ and $U 6$ are benchmarked against the new efficient unit $G$ instead of the older one (U1).

- Finally, since $U 1$ and $U 2$ remain unevaluated, to compute their efficiency scores the same algorithm is repeated excluding the previously evaluated inefficient units $(U 3, U 4, U 5$, and $U 6)$ and calculating a new barycentre for the remaining units. The iteration stops when all units are taken into account.

Note that the efficient units in the data do not change through these steps, only the scores for the inefficient ones are adjusted by shifting the frontier towards $G$ which depends on $\mu$. Also, the convexity assumption of standard DEA is not violated in any of the iterations. The main implication of DEA-SEA methodology is to obtain more optimistic scores for the inefficient units that may be more realistic for the short-term. It weakens the potential drawbacks of the outliers, therefore heterogeneity in the data. Additionally, in the case of multiple efficient units on the frontier, the reference sets for the inefficient units may change via the shift of the frontier towards $G$. This is potentially insightful for setting short term benchmarks, which is also explored in the scope of the empirical application of the current research.

\section{Empirical Application}

\subsection{DEA \& MPI Results}

The data consists of performance indicators of 31 sugar factories operating in Turkey with available data ${ }^{1}$ covering two periods (2017-2018 and 2018-2019). According to the sugar legislation of Turkey, one period corresponds to the dates between $1^{\text {st }}$ of September of

Note that 33 sugar factories are operating in Turkey. Two factories (one public and one privatized) are excluded due to a lack of available data. 
the given year to $31^{\text {st }}$ of August of the succeeding year ${ }^{2}$. Of those 31 factories, the majority were public entities (23 out of 31 ) in the 2017-2018 period. The sector has experienced large scale privatization (corresponding to 9 factories in our data set) in 2018, which results in 14 public, 17 private factories operating in the 2018-2019 period. For measuring the relative efficiency of the factories, we identify three input factors and one output factor presented in Table 2. Sugar production amount is the single output. On the input side, the raw material (sugar beet processed). These factors are common in sugar production efficiency measurement and used in all research presented in Table 1. The number of workers is included in line with the previous literature evaluating the effects of privatization in sugar production (see Mulwa et al., 2009; Demirtas, 2011; Palcic \& Reeves, 2015). We also have operating days as an input factor since the factories differ in their time of operations during the analysis period.

Table: 2

Input and Output Factors

\begin{tabular}{|l|l|c|}
\hline & Factor & Measure \\
\hline Input 1 & Operating Days & Day \\
\hline Input 2 & \# of Workers & Number \\
\hline Input 3 & Sugar Beet Processed & Tons \\
\hline Output & Sugar Production & Tons \\
\hline
\end{tabular}

As a first step to the analysis, CRS-DEA model -as given in (1)- is employed to 31 factories in the data set for both periods. The results can be evaluated in two subsets as public and private factories. Table 3 provides the main characteristics of the data set in terms of ownership together with the efficient factories in both periods. At the end of the first period, 9 factories have been privatized, therefore counted as private factories in the following period.

\section{Table: 3}

\section{Data Set \& Efficient Factories}

\begin{tabular}{|l|c|c|}
\hline & $\mathbf{2 0 1 7 - 2 0 1 8}$ & $\mathbf{2 0 1 8 - 2 0 1 9}$ \\
\hline \# of Public Factories & 23 & 14 \\
\hline \# of Private Factories & 8 & 17 \\
\hline Total \# of Efficient Factories & 5 & 6 \\
\hline Efficient Public Factories & Public 14 & Public 14 \\
\hline Efficient Private Factories & Private 2, Private 3, Private 4, Private 7 & Private 2, Private 3, Private 4, Private 5, Private 7 \\
\hline
\end{tabular}

Efficient factories do not substantially change from one period to another. The ones that are efficient in period 1 are also found to be efficient in period 2 with an additional efficient unit (Private 5). As observed in Table 3, the majority of the efficient units consist of private factories. One efficient factory is Public 14 which is a public entity during both periods. None of the privatized factories are found to be efficient in both periods. The CRS DEA efficiency scores for the individual factories are given in the first columns of Tables A.1 and A.2 of the Appendix for 2017-2018 and 2018-2019 periods, respectively. The

$2<$ https://www.mevzuat.gov.tr/MevzuatMetin/1.5.4634.pdf>, 23.03.2020. 
factories Public 1 to Public 9 in the 2017-2018 period represent the privatized factories, therefore labelled as Private 9 to Private 17 in the 2018-2019 period.

Figure 2 presents the change of average efficiency scores for three main subsets of the units, namely as private factories, public factories, and privatized factories together with the overall change. Interestingly, the only subset of the factories that experience an increase in the average efficiency is the privatized ones. Both public and private factories exhibit a decline in average efficiency scores resulting in a decline overall.

Figure: 2

\section{Average Efficiency Scores}

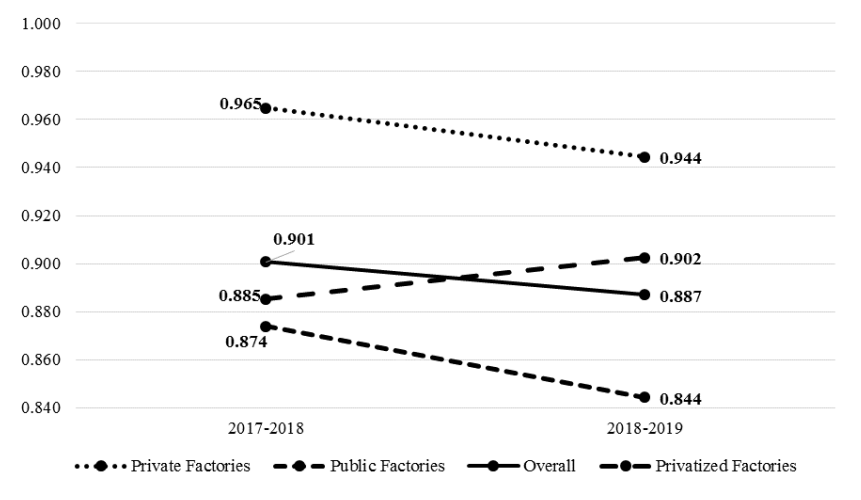

As discussed in Section 3.2, the change in efficiency scores represents only one dimension of the change since the shift of the frontier from one period to another should also be accounted for. Therefore, as a next step, we calculate the Malmquist Productivity Index (MPI) for each unit to observe the change between two periods as given in (2), (3) and (4). Table 4 presents the geometric mean values of MPI and its two components (Efficiency Change - EC and Frontier Shift - FS) for three subsets of the factories.

Table: 4

Malmquist Productivity Index (MPI) Results

\begin{tabular}{|l|c|c|}
\hline & Efficiency Change (EC) & MPI \\
\hline Public Factories & 0.964 & 1.001 \\
\hline Private Factories & 0.976 & 1.004 \\
\hline Privatized Factories & 1.024 & 1.039 \\
\hline Overall & $\mathbf{0 . 9 8 4}$ & 1.029 \\
\hline
\end{tabular}

The $E C$ column of Table 4 reflects what is observed also in Figure 2. The privatized factories subset is the only one that experiences an increase in the $E C$ component. The MPI scores reflect $0.1 \%, 0.4 \%$ and $0.5 \%$ productivity increase for the public, private and privatized factories, respectively. The increase is due to the FS component for public and private units, whereas, for the privatized factories, the level of $E C$ component is the main reason behind the productivity increase. Overall, an increase in productivity by $0.3 \%$ is observed in the sugar production sector and this increase is mainly due to the FS component. 


\subsection{Application of DEA-SEA Method}

Data Envelopment Analysis by Sequential Exclusion of Alternatives (DEA-SEA) methodology, as explained in Section 3, relies on adjusting the efficient frontier to the barycentre of the units so that the effects of heterogeneity in the data set are undermined. Also, by adjusting the frontier closer to the inefficient units, the method reduces the effects of any potential outliers. Furthermore, since the frontier approaches the barycentre, it is possible to obtain more attainable targets for the inefficient units for the shorter terms. In this part, we present the findings of DEA-SEA modelling to our sugar factory data set since heterogeneity to some extent can be assumed due to the fact that both public, private and privatized factories operating in different regions of the country are evaluated in the same set.

Figure: 3

\section{Average Efficiency Scores w.r.t Changing $\mu$}

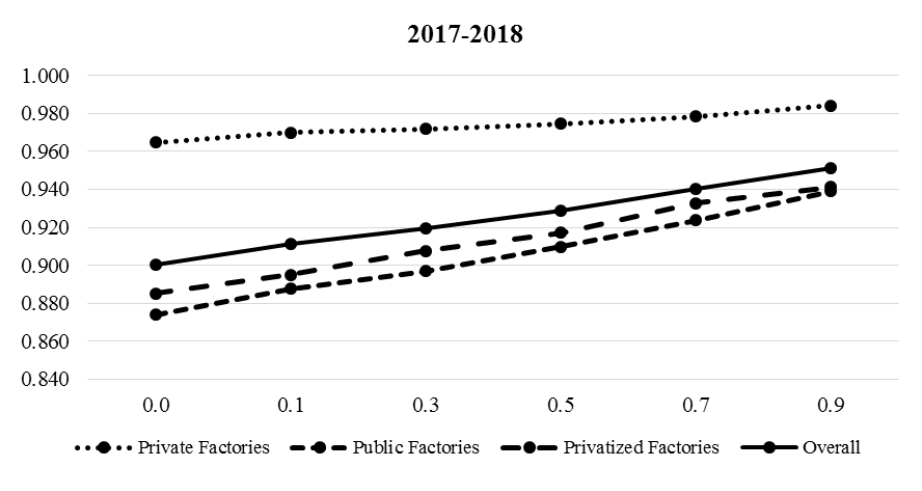

2018-2019

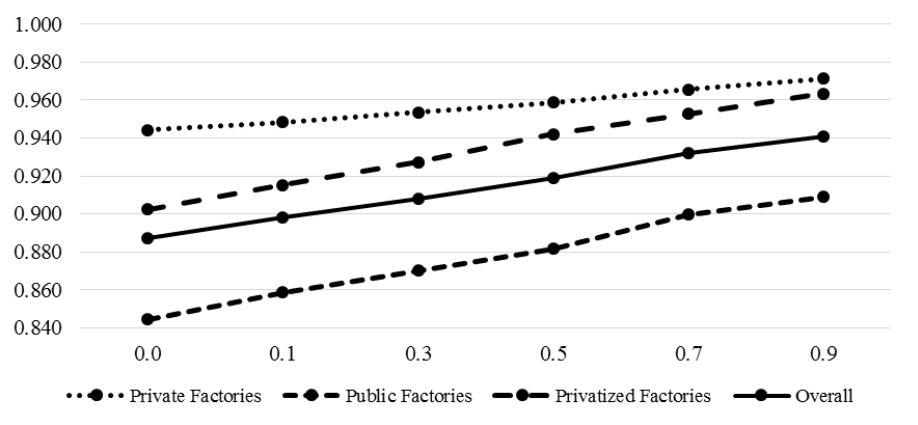

In DEA-SEA, the extent that the frontier is shifted towards the barycentre is controlled by parameter $\mu$ which is between 0 and 1 , where $\mu=0$ stands for the standard CRS DEA case. Increasing the value of $\mu$ represents shifting the units on the initial frontier closer to the barycentre of the units, in other words, obtaining an adjusted frontier. In order 
to observe the effects of changing $\mu$, we calculate efficiency scores of the factories at different $\mu$ levels as $0.1,0.3,0.5,0.7$ and 0.9 . The efficiency scores at the factory-level are presented in Tables A.1 and A.2 of the Appendix for 2017-2018 and 2018-2019 periods, respectively. Figure 3 reveals the change in average efficiency scores of the subsets for both periods. As expected, the average efficiency scores are increasing with respect to changing $\mu$. For both periods, the private factories attain higher levels of efficiency followed by the privatized factory and public factory subsets no matter the $\mu$ value is. Note that the efficient units do not change with the changing $\mu$; however, the scores of the inefficient ones are adjusted.

In order to observe the effects of changing $\mu$ on the efficiency scores, we also calculate the correlation coefficients between the scores at different levels of $\mu$. Table 5 presents the correlation coefficients for both periods' scores. This is to show that as indicated by the original work of Aleskerov \& Petrushchenko (2013), DEA-SEA modelling results in mild changes regarding the scores that means there is no significant shift from the nature of DEA modelling. However, the interpretation is quite insightful in terms of setting targets and reference sets as we discuss below and in the following section.

Table: 5

\section{Correlations between Efficiency Scores at Different Levels of $\mu$}

\begin{tabular}{|c|c|c|c|c|c|c|c|c|c|c|c|c|c|}
\hline \multicolumn{7}{|c|}{ 2017-2018 } & \multicolumn{7}{|c|}{ 2018-2019 } \\
\hline$\mu$ & 0.0 & 0.1 & 0.3 & 0.5 & 0.7 & 0.9 & $\mu$ & 0.0 & 0.1 & 0.3 & 0.5 & 0.7 & 0.9 \\
\hline 0.0 & 1.000 & & & & & & 0.0 & 1.000 & & & & & \\
\hline 0.1 & 0.995 & 1.000 & & & & & 0.1 & 0.996 & 1.000 & & & & \\
\hline 0.3 & 0.989 & 0.996 & 1.000 & & & & 0.3 & 0.991 & 0.998 & 1.000 & & & \\
\hline 0.5 & 0.977 & 0.984 & 0.990 & 1.000 & & & 0.5 & 0.980 & 0.988 & 0.995 & 1.000 & & \\
\hline 0.7 & 0.963 & 0.975 & 0.986 & 0.991 & 1.000 & & 0.7 & 0.964 & 0.974 & 0.984 & 0.990 & 1.000 & \\
\hline 0.9 & 0.935 & 0.949 & 0.958 & 0.967 & 0.984 & 1.000 & 0.9 & 0.951 & 0.965 & 0.975 & 0.981 & 0.986 & 1.000 \\
\hline
\end{tabular}

Here, we would like to refer the efficiency scores with respect to changing $\mu$ as the ranges of pessimistic to optimistic; alternatively, long to short term score for each factory. When the frontier approaches to the barycentre, it also approaches to the inefficient units resulting in a higher efficiency score, which may represent a more optimistic measurement. This optimistic measure, in a way, provides the improvement potential in the short term if the CRS frontier is assumed to the most pessimistic case. Let us illustrate the case for a specific unit. The factory Private 1 has an efficiency score of $86.5 \%$ in the standard CRS model for 2018-2019 period (see the first row of Table A.2 in the Appendix), which means that relatively it is possible to produce 1.156 times higher output (sugar) than its current level with the same input use. This refers to a $15.6 \%$ increase in the output. If this target is seen as too unrealistic for this factory, then it is possible to set more medium-term or short-term targets by adjusting the frontier with $\mu$. The efficiency score at $\mu=0.5$ is $90.5 \%$, which corresponds to a $10.4 \%$ increase in production. If we move further, at $\mu=0.9$, the score is $94.8 \%$, which refers to only a $5.4 \%$ increase. Therefore, the unit can set its path for progress ending up on the frontier in the longer term.

We also observe how average efficiency scores change from period 1 to period 2 at different levels of $\mu$. Figure 4 presents the change in average efficiency scores for $\mu=0.5$ 
and $\mu=0.9$, which are referred to as medium- and short-term performance metrics. The same pattern with the standard DEA model is observed for both $\mu$ values (see Figure 2). Again, the only subset of the factories that experience an increase in the average efficiency is the privatized ones. Both public and private factories exhibit a decline in average efficiency scores resulting in a decline overall.

\section{Figure: 4}

Average Efficiency Scores for $\boldsymbol{\mu}=\mathbf{0 . 5}$ and $\boldsymbol{\mu}=0.9$
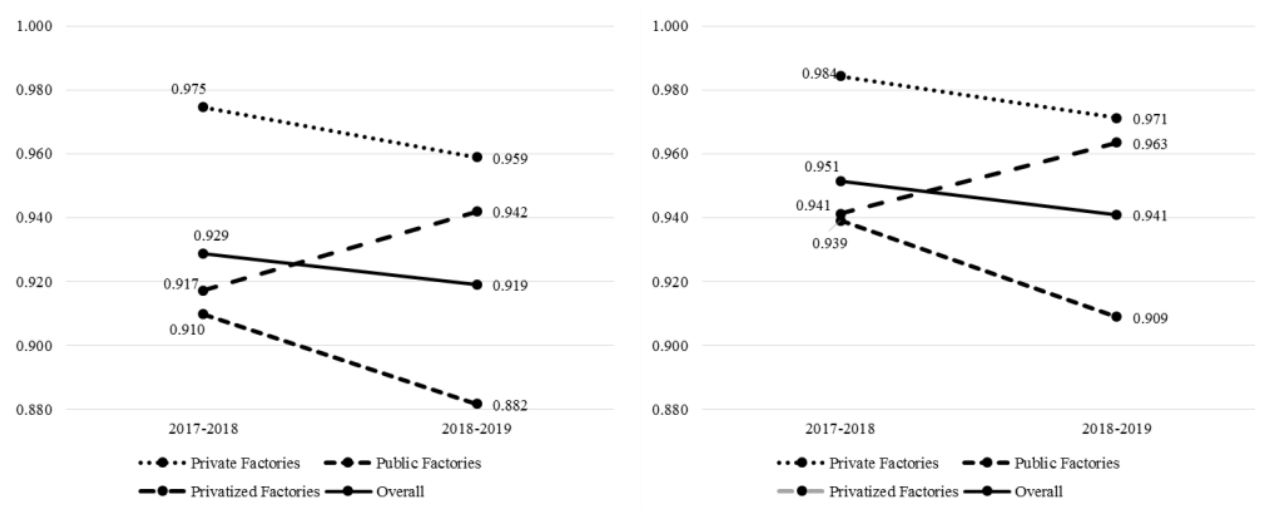

\subsection{Reference Sets}

One of the main outputs of Data Envelopment Analysis (DEA) is the reference set information for the inefficient units to benchmark themselves in order to improve performance. The reference set of a unit consists of the closest units on the efficient frontier. These units are detected through the optimal $\lambda$ values in the DEA model ${ }^{3}$. In this part, we present how the reference sets for the inefficient factories respond to the changing $\mu$ parameter. Tables A.3 and A.4 of the Appendix present the reference sets for the inefficient factories for periods 1 and 2, respectively (period 1 stands for 2017-2018 and period 2 stands for 2018-2019 as noted in section 4.1). The bold values in Tables A.3 and A.4 represent the units that attain the highest weight $(\lambda)$.

As noted, increasing the value of $\mu$ represents shifting the units on the initial frontier (CRS frontier) closer to the barycentre of the units. It is observed that the reference units change for the majority of the units when the frontier (i.e. efficient units) shifts to the direction of the barycentre. As in interpreting the scores, these changing benchmarks can be seen as medium- and short-term references for the units. For instance, the factory Private 1 has $\{$ Private 2, Private 7, Public 14\} as its reference set in period 1 (see Table A.3 of the Appendix), in which Public 14 as its main reference according to the CRS modelling. The reference set changes to $\{$ Private 7 , Public 14$\}$ when $\mu=0.1$ and changes to \{Private 2$\}$ after $\mu=0.3$. This implies that in the medium and short terms, Private 1 can benchmark

3 See Model (1) in Section 3. 
itself to Private 2, whereas in the long term, it should also consider Private 7 and Public 14 as its references. Another observation from Tables A.3 and A.4 is that there is a tendency to a less number of reference units with increasing $\mu$. This can be interpreted as a more focused direction for short-term planning, whereas the number of benchmarking options is increasing for the long-term.

The change in the reference sets can also be observed when the counts of efficient units being in the reference sets are analysed. The numbers are presented in Table 6. As presented earlier, in our sugar factory data set, there are 5 efficient units in period 1 and 6 efficient units in period 2 that serve as the reference units for the inefficient ones (see Table 3). Only one public factory is found to be efficient, namely as Public 14. This factory is a reference to the majority of the factories with respect to the CRS frontier for both periods. When $\mu$ starts to change Private 2 and Private 4 become more predominant as a reference in periods 1 and 2, respectively. In general, the sets shift from the public (namely from Public 14) to private references.

Table: 6

Efficient Units as Main References to Others (\#)

\begin{tabular}{|c|c|c|c|c|c|c|c|c|c|c|c|c|}
\hline & \multicolumn{6}{|c|}{ 2017-2018 } & \multicolumn{6}{|c|}{ 2018-2019 } \\
\hline & CRS & 0.1 & 0.3 & 0.5 & 0.7 & 0.9 & CRS & 0.1 & 0.3 & 0.5 & 0.7 & 0.9 \\
\hline Private 2 & 6 & 4 & 22 & 22 & 20 & 17 & 1 & 1 & 4 & 7 & 5 & 3 \\
\hline Private 3 & 0 & 0 & 1 & 1 & 4 & 7 & 0 & 0 & 0 & 1 & 2 & 4 \\
\hline Private 4 & 1 & 1 & 1 & 1 & 1 & 1 & 0 & 0 & 13 & 16 & 17 & 17 \\
\hline Private 5 & 0 & 0 & 0 & 0 & 0 & 0 & 0 & 0 & 0 & 0 & 0 & 0 \\
\hline Private 7 & 1 & 5 & 0 & 0 & 0 & 0 & 10 & 10 & 7 & 0 & 0 & 0 \\
\hline Public 14 & 18 & 16 & 2 & 2 & 1 & 1 & 14 & 14 & 1 & 1 & 1 & 1 \\
\hline
\end{tabular}

\section{Discussion and Conclusion}

In this research, we explore the effects of the large-scale privatization in the sugar production sector of Turkey, which was mainly held during 2018, on the technical efficiency of the factories. For this aim, first of all, we evaluate the efficiencies of 31 factories for preprivatization (Sept. 2017 - Aug. 2018) and after-privatization (Aug. 2018 - Sept. 2019) periods using Data Envelopment Analysis (DEA) and Malmquist Productivity Index (MPI).

DEA findings reveal that before and after privatization, the majority of the efficient units consists of private factories, only one public factory is efficient. None of the privatized factories are found to be efficient in both periods however, this is the only subset that experiences an increase between periods in the average efficiency. Both public and private factories exhibit a decline in average efficiency scores resulting in a decline overall. On the other hand, the Malmquist Productivity Index (MPI) scores reflect a slight productivity increase for all three subsets of factories $(0.3 \%)$. This means that although average efficiency declines from one period to another, there is a technological improvement resulting in the frontier shift. It can be said that an increase in productivity is observed in the Turkish sugar production sector and this increase is mainly due to the frontier shift component of the MPI.

Moreover, since our data set consists of three subsets of the units, namely as private, public and privatized factories and they operate in different parts of the country; it is possible 
to assume heterogeneity in the sample to some extent. Therefore, when measuring the efficiencies, we also employ one novel extension of the classical Data Envelopment Analysis (DEA) methodology, namely as DEA by Sequential Exclusion of Alternatives (DEA-SEA), which evaluates efficiency by constructing new frontiers taking into account heterogeneity at different levels. The main motivation behind applying DEA-SEA is to obtain adjusted efficiency scores and the reference sets for the factories by tuning the coefficient of heterogeneity $(\mu)$ with different values ranging between 0 and 1 . The higher the $\mu$, the closer the efficient frontier to the barycentre of the units. Therefore, by experimenting with different levels of this parameter, we obtain shorter-term improvement potentials if the standard DEA frontier is assumed to be the longest-term target. Besides, we provide some methodological insights about the DEA-SEA methodology. In order to observe the effects of changing $\mu$, we calculate efficiency scores of the factories at different $\mu$ levels as $0.1,0.3$, 0.5, 0.7 and 0.9, where $\mu=0$ stands for the standard CRS DEA case.

The findings of the DEA-SEA method are evaluated from two perspectives: efficiency scores and reference sets. Regarding the efficiency scores, we calculate five different scores for each factory at different levels of $\mu$. Mainly, we observe the private factories attain higher levels of efficiency followed by privatized and public factory subsets no matter the $\mu$ value is. The correlations between the scores at different levels of the $\mu$ values are found to be quite high, which reflects that changing $\mu$ does not cause a significant shift from the nature of DEA modelling. It means the scores are consistent. We propose to consider the efficiency scores for $\mu=0.5$ and $\mu=0.9$ as to the medium- and short-term performance metrics. In addition, we compare the scores for different $\mu$ for two periods. The same pattern with the standard DEA model is observed for all $\mu$ values as the only subset of the factories that experience an increase in the average efficiency is the privatized ones. Both public and private factories exhibit a decline in average efficiency scores resulting in a decline overall.

On the other hand, one of the main outputs of DEA is the reference set information for the inefficient units to benchmark themselves in order to improve performance. The main implication of DEA-SEA methodology is to obtain more optimistic scores for the inefficient units that may be more realistic for the short-term. It weakens the potential drawbacks of the outliers, therefore heterogeneity in the data. By this approach, one can find the benchmarks for the inefficient factories in both the short and the long terms and aid their future improvement decisions more realistically than using only the classical DEA model. We adopt this characteristic to our data set. This is the first time use of DEA-SEA for setting up shorter-term references. Another observation is that the sets are dominated by private factories rather than the single efficient public factory when $\mu$ increases.

The findings of the current research imply that the recent privatization in the sugar production in Turkey has a reflection on the technical efficiency levels of the factories operating in the sector. The average efficiency in the sector declines, there exists a technological improvement and the privatized factories seem to be improving their performance among the others. We also identified the factor level efficiency scores, which can aid any potential future privatizations. Furthermore, the reference sets identified might 
be a piece of useful information for sugar factories to evaluate their improvement potential. Last but not least, we would like to note that privatization is a complex issue and its effects should be evaluated in different dimensions. Although the current research implies a positive effect for the privatized factories, one should also consider the socio-economic effects to assess any large-scale privatizations. In our case, the factories play a very important role in the provinces' economy and have important effects on the labor force. Therefore, technical efficiency is only one of the multiple dimensions to consider while evaluating the success of any privatization policy.

\section{References}

Abankina, I. et al. (2016), "From equality to diversity: Classifying Russian universities in a performance oriented system", Technological Forecasting and Social Change, 103, 228239.

Aleskerov, F. \& S. Petrushchenko (2013), "DEA by sequential exclusion of alternatives”, Higher School of Economics Working Paper Series, WP7/2013/02.

Aleskerov, F. \& V. Petrushchenko (2015), "DEA for Heterogeneous Samples”, in: H.A. Le Thi \& T.P. Dinh \& N.T. Nguyen (eds.), Modelling, Computation and Optimization in Information Systems and Management Sciences, Springer, Cham, 15-21.

Atici, K.B. \& V.V. Podinovski (2012), A Review of Data Envelopment Analysis studies in Agriculture, <http://fadntool.sggw.pl/Reviews/Downld?file=WP5_LR.pdf>, 28.01.2020.

Bogetoft, P. et al. (2007), "Reallocating sugar beet contracts: can sugar production survive in Denmark?", European Review of Agricultural Economics, 34(1), 1-20.

Borgheipour, H. \& F.H. Lotfi \& Z. Moghaddas (2017), "Implementing energy efficiency for target setting in the sugar industry of Iran", International Journal of Environmental Science and Technology, 14(8), 1697-1712.

Caves, D.W. \& L.R. Christensen \& W.E. Diewert (1982), "The economic theory of index numbers and the measurement of input, output, and productivity", Econometrica: Journal of the Econometric Society, 1393-1414.

Charnes, A. \& W.W. Cooper \& E. Rhodes (1978), "Measuring the efficiency of decision making units", European Journal of Operational Research, 2(6), 429-444.

Cicek, O. \& C. Şahin (2018), "Debating Cooperatives as an Alternative to Privatization of Sugar Mills in Turkey: The Case of Burdur Sugar Mill”, in: M.M. Erdoğdu \& M.S. Zouboulakis \& S.M. Akar \& B. Turan-İçke (eds), Public Sector Economics \& Development, London: IJOPEC Publication, 91-102.

Cinar, Y. (2013), "Research and Teaching Efficiencies of Turkish Universities with Heterogeneity Considerations: Application of Multi-Activity DEA and DEA by Sequential Exclusion of Alternatives Methods", Higher School of Economics Working Paper Series, WP7/2013/04.

De Koeijer, T.J. et al. (2002), "Measuring agricultural sustainability in terms of efficiency: the case of Dutch sugar beet growers", Journal of Environmental Management, 66(1), 9-18.

Demirtas, E.A. (2011), “A data envelopment-based clustering approach for public sugar factories in privatizing process", Mathematical Problems in Engineering, 2011. 
Duarte, A. et al. (2019). "Proposal of operating best practices that contribute to the technical efficiency in Brazilian sugar and ethanol mills", Journal of Cleaner Production, 214, 173-184.

Emrouznejad, A. \& B.R. Parker \& G. Tavares (2008), "Evaluation of research in efficiency and productivity: A survey and analysis of the first 30 years of scholarly literature in DEA", Socio-Economic Planning Sciences, 42(3), 151-157.

F.O. Licht's (2019), “International highlights”, International Sugar and Sweetener Report. 151(16), 343.

Färe, R. et al. (1992), "Productivity changes in Swedish pharmacies 1980-1989: A non-parametric Malmquist approach", Journal of Productivity Analysis, 3(1-2), 85-101.

Ferrantino, M.J. \& G.D. Ferrier (1995), "The technical efficiency of vacuum-pan sugar industry of India: An application of a stochastic frontier production function using panel data", European Journal of Operational Research, 80(3), 639-653.

Fogarasi, J. (2007), "Efficiency and total factor productivity in post-EU accession Hungarian sugar beet production”, Studies in Agricultural Economics, 105(1316-2016-102771), 87-100.

Goncharuk, A.G. (2009), "How to make sugar production more effective: A case of Ukraine", Journal for East European Management Studies, 105-123.

Johnson, J.L. \& H.O. Zapata \& A.M. Heagler (1995), "Technical efficiency in Louisiana sugar cane processing", Journal of Agribusiness, 13(345-2016-15422), 85-98.

Kumar, S. \& N. Arora (2011), "Assessing technical efficiency of sugar industry in Uttar Pradesh: An application of data envelopment analysis", Indian Economic Review, 323-353.

Mulwa, M.R. \& A. Emrouznejad \& F.M. Murithi (2009), "Impact of liberalization on efficiency and productivity of sugar industry in Kenya”, Journal of Economic Studies, 36(3), 250-264.

Murali, P. \& D.P. Prathap (2017), "Technical efficiency of sugarcane farms: an econometric analysis", Sugar Tech, 19(2), 109-116.

Murty, M.N. \& S. Kumar \& M. Paul (2006), "Environmental regulation, productive efficiency and cost of pollution abatement: a case study of the sugar industry in India", Journal of Environmental Management, 79(1), 1-9.

Palcic, D. \& E. Reeves (2015), "Privatization and the economic performance of Irish Sugar/Greencore", Applied Economics, 47(55), 5945-5961.

Patlolla, S. \& R.E. Goodhue \& R.J. Sexton (2012), "Price floors and technical inefficiency in India's sugar processing industry", Agricultural Economics, 43(1), 105-114.

Raheman, A. et al. (2009), "Efficiency dynamics of sugar industry of Pakistan [with comments]", The Pakistan Development Review, 921-938.

Seiford, L.M. \& R.M. Thrall (1990), "Recent developments in DEA: the mathematical programming approach to frontier analysis", Journal of Econometrics, 46(1-2), 7-38.

Ullah, A. et al. (2019), "Efficiency analysis of sugarcane production systems in Thailand using data envelopment analysis", Journal of Cleaner Production, 238, 117877.

USDA Foreign Agriculture Service (2020), Turkey Sugar Annual Report 2019, $<$ https://apps.fas.usda.gov/>, 24.01.2020.

Wu, S. \& S. Devadoss \& Y. Lu (2003), "Estimation and decomposition of technical efficiency for sugarbeet farms", Applied Economics, 35(4), 471-484.

Ye, J. et al. (2016), "Evaluating sugarcane productivity in China over different periods using data envelopment analysis and the Malmquist index", Sugar Tech, 18(5), 478-487. 
Çınar, Y. \& K.B. Atıcı \& C. Menten (2021), "Evaluating Technical Efficiency of Turkish

Sugar Production in Pre and Post Privatization Periods", Sosyoekonomi, 29(47), 59-78.

\section{Appendix}

Table: A.1.

Efficiency Scores (2017-2018)

\begin{tabular}{|c|c|c|c|c|c|c|c|}
\hline & Factory & CRS & 0.1 & 0.3 & 0.5 & 0.7 & 0.9 \\
\hline 1 & Private 1 & 0.888 & 0.901 & 0.911 & 0.924 & 0.941 & 0.965 \\
\hline 2 & Private 2 & 1.000 & 1.000 & 1.000 & 1.000 & 1.000 & 1.000 \\
\hline 3 & Private 3 & 1.000 & 1.000 & 1.000 & 1.000 & 1.000 & 1.000 \\
\hline 4 & Private 4 & 1.000 & 1.000 & 1.000 & 1.000 & 1.000 & 1.000 \\
\hline 5 & Private 5 & 0.997 & 0.998 & 0.999 & 0.999 & 0.998 & 0.998 \\
\hline 6 & Private 6 & 0.985 & 0.999 & 0.993 & 0.991 & 0.991 & 0.988 \\
\hline 7 & Private 7 & 1.000 & 1.000 & 1.000 & 1.000 & 1.000 & 1.000 \\
\hline 8 & Private 8 & 0.849 & 0.861 & 0.871 & 0.883 & 0.899 & 0.923 \\
\hline 9 & Public 1 & 0.944 & 0.962 & 0.994 & 0.958 & 0.996 & 0.981 \\
\hline 10 & Public 2 & 0.865 & 0.873 & 0.882 & 0.894 & 0.910 & 0.941 \\
\hline 11 & Public 3 & 0.909 & 0.913 & 0.944 & 0.987 & 0.988 & 0.963 \\
\hline 12 & Public 4 & 0.839 & 0.847 & 0.856 & 0.868 & 0.884 & 0.907 \\
\hline 13 & Public 5 & 0.657 & 0.668 & 0.675 & 0.684 & 0.697 & 0.715 \\
\hline 14 & Public 6 & 0.982 & 0.996 & 0.990 & 0.989 & 1.000 & 0.998 \\
\hline 15 & Public 7 & 0.951 & 0.957 & 0.967 & 0.991 & 0.981 & 0.971 \\
\hline 16 & Public 8 & 0.918 & 0.932 & 0.943 & 0.955 & 0.973 & 0.999 \\
\hline 17 & Public 9 & 0.901 & 0.907 & 0.917 & 0.929 & 0.966 & 0.996 \\
\hline 18 & Public 10 & 0.926 & 0.955 & 0.966 & 0.979 & 0.997 & 0.993 \\
\hline 19 & Public 11 & 0.846 & 0.863 & 0.873 & 0.885 & 0.901 & 0.925 \\
\hline 20 & Public 12 & 0.894 & 0.902 & 0.911 & 0.924 & 0.941 & 0.967 \\
\hline 21 & Public 13 & 0.874 & 0.900 & 0.911 & 0.923 & 0.940 & 0.965 \\
\hline 22 & Public 14 & 1.000 & 1.000 & 1.000 & 1.000 & 1.000 & 1.000 \\
\hline 23 & Public 15 & 0.889 & 0.894 & 0.903 & 0.931 & 0.921 & 0.953 \\
\hline 24 & Public 16 & 0.885 & 0.892 & 0.901 & 0.917 & 0.943 & 0.941 \\
\hline 25 & Public 17 & 0.885 & 0.890 & 0.899 & 0.917 & 0.946 & 0.969 \\
\hline 26 & Public 18 & 0.911 & 0.946 & 0.958 & 0.971 & 0.988 & 0.994 \\
\hline 27 & Public 19 & 0.872 & 0.885 & 0.895 & 0.907 & 0.923 & 0.948 \\
\hline 28 & Public 20 & 0.820 & 0.833 & 0.842 & 0.853 & 0.869 & 0.892 \\
\hline 29 & Public 21 & 0.604 & 0.610 & 0.617 & 0.625 & 0.636 & 0.653 \\
\hline 30 & Public 22 & 0.868 & 0.886 & 0.896 & 0.908 & 0.925 & 0.949 \\
\hline 31 & Public 23 & 0.961 & 0.974 & 0.985 & 0.998 & 1.000 & 0.997 \\
\hline
\end{tabular}

Note: Public 1-9 are privatized in the following year. 
Çınar, Y. \& K.B. Atıcı \& C. Menten (2021), "Evaluating Technical Efficiency of Turkish

Sugar Production in Pre and Post Privatization Periods", Sosyoekonomi, 29(47), 59-78.

Table: A.2.

Efficiency Scores (2018-2019)

\begin{tabular}{|c|c|c|c|c|c|c|}
\hline Factory & CRS & 0.1 & 0.3 & 0.5 & 0.7 & 0.9 \\
\hline Private 1 & 0.865 & 0.875 & 0.890 & 0.905 & 0.922 & 0.948 \\
\hline Private 2 & 1.000 & 1.000 & 1.000 & 1.000 & 1.000 & 1.000 \\
\hline Private 3 & 1.000 & 1.000 & 1.000 & 1.000 & 1.000 & 1.000 \\
\hline Private 4 & 1.000 & 1.000 & 1.000 & 1.000 & 1.000 & 1.000 \\
\hline Private 5 & 1.000 & 1.000 & 1.000 & 1.000 & 1.000 & 1.000 \\
\hline Private 6 & 0.933 & 0.945 & 0.960 & 0.976 & 0.995 & 0.990 \\
\hline Private 7 & 1.000 & 1.000 & 1.000 & 1.000 & 1.000 & 1.000 \\
\hline Private 8 & 0.757 & 0.768 & 0.778 & 0.790 & 0.807 & 0.831 \\
\hline Private 9 & 0.870 & 0.878 & 0.893 & 0.909 & 0.926 & 0.946 \\
\hline Private 10 & 0.909 & 0.924 & 0.938 & 0.952 & 0.971 & 0.980 \\
\hline Private 11 & 0.887 & 0.893 & 0.916 & 0.962 & 0.950 & 0.939 \\
\hline Private 12 & 0.829 & 0.837 & 0.852 & 0.866 & 0.883 & 0.911 \\
\hline Private 13 & 0.833 & 0.857 & 0.869 & 0.882 & 0.901 & 0.928 \\
\hline Private 14 & 0.968 & 0.989 & 0.995 & 0.993 & 0.993 & 0.999 \\
\hline Private 15 & 0.988 & 0.997 & 0.996 & 0.994 & 0.993 & 0.991 \\
\hline Private 16 & 0.907 & 0.925 & 0.937 & 0.952 & 0.972 & 0.981 \\
\hline Private 17 & 0.929 & 0.937 & 0.951 & 0.966 & 0.985 & 0.994 \\
\hline Public 10 & 0.938 & 0.967 & 0.980 & 0.996 & 0.989 & 0.992 \\
\hline Public 11 & 0.784 & 0.798 & 0.810 & 0.822 & 0.839 & 0.864 \\
\hline Public 12 & 0.821 & 0.831 & 0.844 & 0.859 & 0.875 & 0.900 \\
\hline Public 13 & 0.837 & 0.863 & 0.875 & 0.889 & 0.908 & 0.935 \\
\hline Public 14 & 1.000 & 1.000 & 1.000 & 1.000 & 1.000 & 1.000 \\
\hline Public 15 & 0.887 & 0.894 & 0.908 & 0.921 & 0.972 & 0.937 \\
\hline Public 16 & 0.814 & 0.820 & 0.833 & 0.846 & 0.876 & 0.881 \\
\hline Public 17 & 0.854 & 0.860 & 0.873 & 0.890 & 0.921 & 0.910 \\
\hline Public 18 & 0.940 & 0.976 & 0.989 & 0.987 & 0.998 & 0.997 \\
\hline Public 19 & 0.828 & 0.842 & 0.854 & 0.868 & 0.885 & 0.911 \\
\hline Public 20 & 0.829 & 0.845 & 0.857 & 0.870 & 0.888 & 0.915 \\
\hline Public 21 & 0.570 & 0.576 & 0.585 & 0.594 & 0.606 & 0.624 \\
\hline Public 22 & 0.782 & 0.798 & 0.809 & 0.822 & 0.840 & 0.865 \\
\hline Public 23 & 0.935 & 0.949 & 0.963 & 0.979 & 0.998 & 0.995 \\
\hline
\end{tabular}


Table: A.3.

Reference Sets (2017-2018)

\begin{tabular}{|c|c|c|c|c|c|c|}
\hline & 0 (CRS) & 0.1 & 0.3 & 0.5 & 0.7 & 0.9 \\
\hline Private 1 & Private 2, Private 7, Public 14 & Private 7, Public 14 & \begin{tabular}{|l|} 
Private 2 \\
\end{tabular} & \begin{tabular}{|l|} 
Private 2 \\
\end{tabular} & \begin{tabular}{|l|} 
Private 2 \\
\end{tabular} & \begin{tabular}{|l|} 
Private 2 \\
\end{tabular} \\
\hline Private 5 & Private 2 , Private 3 , Private 4 & Private 3, Private 4 & Private 3, Private 4 & Private 3 , Private 4 & Private 3 , Private 4 & \\
\hline Private 6 & Private 2, Public 14 & Private 7, Public 14 & & & & \\
\hline Private 8 & Private 7, Public 14 & & \begin{tabular}{|l|} 
Private 2 \\
\end{tabular} & \begin{tabular}{|l|} 
Private 2 \\
\end{tabular} & \begin{tabular}{|l|} 
Private 2 \\
\end{tabular} & \begin{tabular}{|l|} 
Private 2 \\
\end{tabular} \\
\hline Public 1 & Private 2, Private 3 & & \begin{tabular}{|l|} 
Private 3 \\
\end{tabular} & & \begin{tabular}{|l|} 
Private 3 \\
\end{tabular} & \\
\hline Public 2 & Private 2, Public 14 & & \begin{tabular}{|l|} 
Private 2 \\
\end{tabular} & \begin{tabular}{|l|} 
Private 2 \\
\end{tabular} & \begin{tabular}{|l|} 
Private 2 \\
\end{tabular} & Private 2, Private 3 \\
\hline Public 3 & Private 2, Public 14 & & & \begin{tabular}{|l|} 
Private 3 \\
\end{tabular} & \begin{tabular}{|l|} 
Private 3 \\
\end{tabular} & Private 2, Private 3 \\
\hline Public 4 & Private 2, Public 14 & & \begin{tabular}{|l|} 
Private 2 \\
\end{tabular} & \begin{tabular}{|l|} 
Private 2 \\
\end{tabular} & \begin{tabular}{|l|} 
Private 2 \\
\end{tabular} & Private 2 \\
\hline Public 5 & Private 2, Public 14 & Private 7, Public 14 & \begin{tabular}{|l|} 
Private 2 \\
\end{tabular} & \begin{tabular}{|l|} 
Private 2 \\
\end{tabular} & \begin{tabular}{|l|} 
Private 2 \\
\end{tabular} & \begin{tabular}{|l|} 
Private 2 \\
\end{tabular} \\
\hline Public 6 & \begin{tabular}{|l|} 
Private 2, Public 14 \\
\end{tabular} & Private 7, Public 14 & & & \begin{tabular}{|l|} 
Private 2 \\
\end{tabular} & \begin{tabular}{|l|} 
Private 2 \\
\end{tabular} \\
\hline Public 7 & Private 2, Public 14 & Private 2, Private 7 & \begin{tabular}{|l|} 
Private 2 \\
\end{tabular} & Private 2, Private 3 & Private 2, Private 3 & Private 2, Private 3 \\
\hline Public 8 & Private 2, Public 14 & Private 7, Public 14 & \begin{tabular}{|l|} 
Private 2 \\
\end{tabular} & \begin{tabular}{|l|} 
Private 2 \\
\end{tabular} & Private 2 & \begin{tabular}{|l|} 
Private 2 \\
\end{tabular} \\
\hline Public 9 & Private 2, Public 14 & Private 2, Private 7 & \begin{tabular}{|l|} 
Private 2 \\
\end{tabular} & \begin{tabular}{|l|} 
Private 2 \\
\end{tabular} & Private 2, Private 3 & \begin{tabular}{|l|} 
Private 3 \\
\end{tabular} \\
\hline Public 10 & Private 7, Public 14 & \begin{tabular}{|l|} 
Public 14 \\
\end{tabular} & \begin{tabular}{|l|} 
Private 2 \\
\end{tabular} & \begin{tabular}{|l|} 
Private 2 \\
\end{tabular} & \begin{tabular}{|l|} 
Private 2 \\
\end{tabular} & \begin{tabular}{|l|} 
Private 2 \\
\end{tabular} \\
\hline Public 11 & Private 2, Private 7, Public 14 & Private 7, Public 14 & \begin{tabular}{|l|} 
Private 2 \\
\end{tabular} & \begin{tabular}{|l|} 
Private 2 \\
\end{tabular} & \begin{tabular}{|l|} 
Private 2 \\
\end{tabular} & \begin{tabular}{|l|} 
Private 2 \\
\end{tabular} \\
\hline Public 12 & Private 2, Public 14 & Private 2, Private 7 & \begin{tabular}{|l|} 
Private 2 \\
\end{tabular} & \begin{tabular}{|l|} 
Private 2 \\
\end{tabular} & \begin{tabular}{|l|} 
Private 2 \\
\end{tabular} & Private 2, Private 3 \\
\hline Public 13 & Private 2, Public 14 & \begin{tabular}{|l|} 
Public 14 \\
\end{tabular} & \begin{tabular}{|l|} 
Private 2 \\
\end{tabular} & \begin{tabular}{|l|} 
Private 2 \\
\end{tabular} & \begin{tabular}{|l|} 
Private 2 \\
\end{tabular} & \begin{tabular}{|l|} 
Private 2 \\
\end{tabular} \\
\hline Public 15 & Private 2, Public 14 & Private 2, Private 7 & \begin{tabular}{|l|} 
Private 2 \\
\end{tabular} & Private 2, Private 3 & Private 2, Private 3 & \begin{tabular}{|l|} 
Private 3 \\
\end{tabular} \\
\hline Public 16 & Private 2, Private 7, Public 14 & Private 2, Private 7 & \begin{tabular}{|l|} 
Private 2 \\
\end{tabular} & Private 2, Private 3 & Private 2, Private 3 & Private 2, Private 3 \\
\hline Public 17 & Private 2, Private 7, Public 14 & Private 2, Private 7 & \begin{tabular}{|l|} 
Private 2 \\
\end{tabular} & Private 2, Private 3 & Private 2, Private 3 & Private 3 \\
\hline Public 18 & \begin{tabular}{|l|} 
Public 14 \\
\end{tabular} & & \begin{tabular}{|l|} 
Private 2 \\
\end{tabular} & \begin{tabular}{|l|} 
Private 2 \\
\end{tabular} & \begin{tabular}{|l|} 
Private 2 \\
\end{tabular} & \begin{tabular}{|l|} 
Private 2 \\
\end{tabular} \\
\hline Public 19 & Private 2, Public 14 & Private 7, Public 14 & \begin{tabular}{|l|} 
Private 2 \\
\end{tabular} & \begin{tabular}{|l|} 
Private 2 \\
\end{tabular} & \begin{tabular}{|l|} 
Private 2 \\
\end{tabular} & \begin{tabular}{|l|} 
Private 2 \\
\end{tabular} \\
\hline Public 20 & Private 2, Public 14 & Private 7, Public 14 & \begin{tabular}{|l|} 
Private 2 \\
\end{tabular} & \begin{tabular}{|l|} 
Private 2 \\
\end{tabular} & \begin{tabular}{|l|} 
Private 2 \\
\end{tabular} & \begin{tabular}{|l|} 
Private 2 \\
\end{tabular} \\
\hline Public 21 & Private 2, Public 14 & Private 2, Private 7 & \begin{tabular}{|l|} 
Private 2 \\
\end{tabular} & \begin{tabular}{|l|} 
Private 2 \\
\end{tabular} & \begin{tabular}{|l|} 
Private 2 \\
\end{tabular} & \begin{tabular}{|l|} 
Private 2 \\
\end{tabular} \\
\hline Public 22 & Private 2, Public 14 & Private 7, Public 14 & \begin{tabular}{|l|} 
Private 2 \\
\end{tabular} & \begin{tabular}{|l|} 
Private 2 \\
\end{tabular} & \begin{tabular}{|l|} 
Private 2 \\
\end{tabular} & \begin{tabular}{|l|} 
Private 2 \\
\end{tabular} \\
\hline Public 23 & Private 2, Public 14 & Private 7, Public 14 & \begin{tabular}{|l|} 
Private 2 \\
\end{tabular} & \begin{tabular}{|l|} 
Private 2 \\
\end{tabular} & \begin{tabular}{|l|} 
Private 2 \\
\end{tabular} & \begin{tabular}{|l|} 
Private 2 \\
\end{tabular} \\
\hline
\end{tabular}

Notes: The blank cells mean that the reference set does not change from one $\mu$ to another (left to the right). Bold ones represent main reference (highest $\lambda$ ) 
Table: A.4.

Reference Sets (2018-2019)

\begin{tabular}{|c|c|c|c|c|c|c|}
\hline & 0 (CRS) & 0.1 & 0.3 & 0.5 & $\begin{array}{l}0.7 \\
\end{array}$ & 0.9 \\
\hline Private 1 & Private 7, Public 14 & & Private 4, Private 7 & Private 2, Private 4 & Private 2, Private 4 & Private 2, Private 4 \\
\hline Private 6 & Private 7, Public 14 & & Private 4, Private 7 & Private 2, Private 4 & Private 2, Private 4 & \begin{tabular}{|l|} 
Private 4 \\
\end{tabular} \\
\hline Private 8 & Private 4, Private 7, Public 14 & \begin{tabular}{|l|} 
Private 7, Public 14 \\
\end{tabular} & \begin{tabular}{|l|} 
Private 4 \\
\end{tabular} & Private 4 & Private 4 & \begin{tabular}{|l|} 
Private 4 \\
\end{tabular} \\
\hline Private 9 & Private 7, Public 14 & & Private 2, Private 7 & Private 2, Private 4 & Private 2, Private 4 & \begin{tabular}{|l|} 
Private 2 , Private 3 \\
\end{tabular} \\
\hline Private 10 & Private 7, Public 14 & & Private 4, Private 7 & Private 2, Private 4 & Private 2, Private 4 & Private 4 \\
\hline Private 11 & Private 2, Private 7 & & Private 2, Private 3 & Private 2, Private 3 & Private 2, Private 3 & Private 2, Private 3 \\
\hline Private 12 & Private 7, Public 14 & & Private 4, Private 7 & Private 2, Private 4 & Private 2, Private 4 & Private 2, Private 3 \\
\hline Private 13 & Private 7, Public 14 & & \begin{tabular}{|l|} 
Private 4 \\
\end{tabular} & \begin{tabular}{|l|} 
Private 4 \\
\end{tabular} & Private 4 & \begin{tabular}{|l|} 
Private 4 \\
\end{tabular} \\
\hline Private 14 & Private 7, Public 14 & & \begin{tabular}{|l|} 
Private 4 \\
\end{tabular} & Private 4 & Private 4 & Private 4 \\
\hline Private 15 & Private 7, Public 14 & & & & & \\
\hline Private 16 & Private 7, Public 14 & & Private 4, Private 7 & \begin{tabular}{|l|} 
Private 4 \\
\end{tabular} & Private 4 & \begin{tabular}{|l|} 
Private 4 \\
\end{tabular} \\
\hline Private 17 & Private 4, Private 7, Public 14 & \begin{tabular}{|l|} 
Private 4, Private 7 \\
\end{tabular} & Private 4, Private 7 & Private 2, Private 4 & Private 2, Private 4 & Private 4 \\
\hline Public 10 & \begin{tabular}{|l} 
Private 4, Private 7, Public 14 \\
\end{tabular} & \begin{tabular}{|l|} 
Public 14 \\
\end{tabular} & \begin{tabular}{|l|} 
Private 4 \\
\end{tabular} & \begin{tabular}{|l|} 
Private 4 \\
\end{tabular} & Private 4 & \begin{tabular}{|l|} 
Private 4 \\
\end{tabular} \\
\hline Public 11 & Private 7, Public 14 & & Private 4, Private 7 & Private 2, Private 4 & Private 4 & \begin{tabular}{|l|} 
Private 4 \\
\end{tabular} \\
\hline Public 12 & Private 7, Public 14 & & Private 4, Private 7 & Private 2, Private 4 & Private 2, Private 4 & Private 2, Private 4 \\
\hline Public 13 & Private 7, Public 14 & \begin{tabular}{|l|} 
Public 14 \\
\end{tabular} & \begin{tabular}{|l|} 
Private 4 \\
\end{tabular} & \begin{tabular}{|l|} 
Private 4 \\
\end{tabular} & Private 4 & \begin{tabular}{|l|} 
Private 4 \\
\end{tabular} \\
\hline Public 15 & Private 2, Private 7 & & Private 2, Private 7 & Private 2, Private 4 & Private 2, Private 3 & Private 2, Private 3 \\
\hline Public 16 & Private 2, Private 4 , Private 7 & & & Private 2, Private 3 , Private 4 & Private 2, Private 3 , Private 4 & Private 2, Private 3 \\
\hline Public 17 & Private 2, Private 4 , Private 7 & & & Private 2, Private 3 , Private 4 & Private 2, Private 3 , Private 4 & Private 2 , Private 3 \\
\hline Public 18 & \begin{tabular}{|l|} 
Public 14 \\
\end{tabular} & & \begin{tabular}{|l|} 
Private 4 \\
\end{tabular} & \begin{tabular}{|l|} 
Private 4 \\
\end{tabular} & Private 4 & Private 4 \\
\hline Public 19 & Private 7, Public 14 & & Private 4, Private 7 & Private 2, Private 4 & Private 2, Private 4 & \begin{tabular}{|l|} 
Private 4 \\
\end{tabular} \\
\hline Public 20 & Private 7, Public 14 & & Private 4, Private 7 & Private 2, Private 4 & Private 4 & \begin{tabular}{|l|} 
Private 4 \\
\end{tabular} \\
\hline Public 21 & Private 4, Private 7, Public 14 & \begin{tabular}{|l|} 
Private 7, Public 14 \\
\end{tabular} & Private 4, Private 7 & Private 2, Private 4 & Private 2, Private 4 & \begin{tabular}{|l|} 
Private 4 \\
\end{tabular} \\
\hline Public 22 & Private 7, Public 14 & & \begin{tabular}{|l|} 
Private 4 \\
\end{tabular} & \begin{tabular}{|l|} 
Private 4 \\
\end{tabular} & \begin{tabular}{|l|} 
Private 4 \\
\end{tabular} & \begin{tabular}{|l|} 
Private 4 \\
\end{tabular} \\
\hline Public 23 & Private 7, Public 14 & & Private 4, Private 7 & Private 2, Private 4 & Private 2, Private 4 & \begin{tabular}{|l|} 
Private 4 \\
\end{tabular} \\
\hline
\end{tabular}

Notes: The blank cells mean that the reference set does not change from one $\mu$ to another (left to the right). Bold ones represent the main reference (highest $\lambda$ ). 